\title{
20. DATA REPORT: MIOCENE PALYNOLOGIC AND CLIMATIC RECORDS, NEW JERSEY COASTAL PLAIN ${ }^{1}$
}

\author{
Gilbert J. Brenner, ${ }^{2}$ Peter J. Sugarman, ${ }^{3}$ and Kenneth G. Miller ${ }^{4}$
}

\section{INTRODUCTION}

Major changes in global climate occurred during the Miocene. Deep-sea $\delta^{18} \mathrm{O}$ values provide the most detailed record of ice volume and global climate changes. General global warming in the late Oligocene to early Miocene was punctuated by at least four early Miocene glaciations (Mi1, Mi1a, Mi1b, and Mi2 of Miller et al., 1991). A major climatic transition began following the zenith of warmth in the late early to early middle Miocene ( 17-15 Ma). A transient cooling/glaciation at $\sim 16.5 \mathrm{Ma}$ (= Mi2 of Miller et al., 1991) was followed by a warming and then a subsequent regrowth of the East Antarctic Ice Sheet from $\sim 15$ to $13 \mathrm{Ma}$ (Miller et al., 1991; Flower and Kennett, 1994). Oceanic latitudinal thermal gradients increased in the middle Miocene (Savin et al., 1985). Although marine records constrain the timing of oceanographic and ice volume changes, there are few terrestrial or near-shore records of Miocene temperature history.

The New Jersey Coastal Plain Drilling Project (Ocean Drilling Program [ODP] Leg 150X) recovered thick near-shore Miocene sections that have been dated using Sr-isotopic stratigraphy (Miller, et al., 1994; Miller et al., 1996b; Miller et al., Chapter 14, this volume; Sugarman et al., Chapter 12, this volume). In this paper, we present Miocene pollen data collected from these and other boreholes in New Jersey (Fig. 1). Stratigraphic coverage of the pollen data is limited at present; however, our data provide evidence not only for longer term climate cooling during the Miocene but also for within-sequence variations in terrestrial temperatures.

\section{METHODS}

\section{Stratigraphic Sections}

Stratigraphic sections (Figs. 2, 3) were developed from published studies of Miocene boreholes in New Jersey (Owens et al., 1988; Sugarman et al., 1993; Miller, et al., 1994, 1996a; Owens et al., 1995a, 1995b). The Miocene sections, typically comprising clays and sands deposited in prodelta and shallow shelf (inner-middle neritic; 0-100 m paleodepth) environments, are assigned to the Kirkwood Formation (Sugarman et al., 1993; Miller et al., Chapter 14, this volume). Stratigraphic sequences were identified as unconformitybounded transgressive-regressive sequences that typically shoal upward. Unconformities were identified using physical stratigraphy, biostratigraphy, and Sr-isotope stratigraphy. Miocene sequences were termed Kw0, Kw1a, Kw1b, Kw1c, Kw2a, Kw2b, Kw2c, Kw3, and $\mathrm{Kw}-\mathrm{Cohansey}(\mathrm{Kw}-\mathrm{C})$. The sequences typically consist of a lower silt and an upper quartz sand that coarsen and shallow upsection as

${ }^{1}$ Miller, K.G., and Snyder, S.W. (Eds.), 1997. Proc. ODP, Sci. Results, 150X: College Station, TX (Ocean Drilling Program).

${ }^{2}$ Department of Geological Services, State University of New York, New Paltz, NY 12561, U.S.A.

${ }^{3}$ Correspondence author: New Jersey Geological Survey, CN427, Trenton, NJ 08625, U.S.A.petes@njgs.dep.state.nj.us

${ }^{4}$ Department of Geology, Rutgers University, Piscataway, NJ 08855, U.S.A. a result of progradation. Lowermost Miocene sequences Kw0 and Kw1a have basal glauconite sands reflecting the deepest paleodepths.

\section{Palynology}

This report uses previously published, unpublished, and new pollen data (Tables 1-3; Plates 1,2) for paleoclimatic interpretations of lower to middle Miocene sediments from the New Jersey Coastal Plain. T. Ager (in Owens et al., 1988) studied pollen from the ACGS\#4 borehole. Ager (pers. comm., 1994) also performed a preliminary analysis of pollen from Miocene sediments at the Leg 150X Island Beach borehole. Pollen from the Belleplain State Forest borehole was identified by L. Sirkin (pers. comm., 1991). New data presented in this study are chiefly from the Leg 150X Atlantic City borehole (Table 2), and the Cape May borehole (Table 3).

Paleoclimatic indicators were based on pollen genera outlined in Table 1. Three generalized climatic assemblages were identified, including (1) warm temperate to subtropical, (2) temperate, and (3)

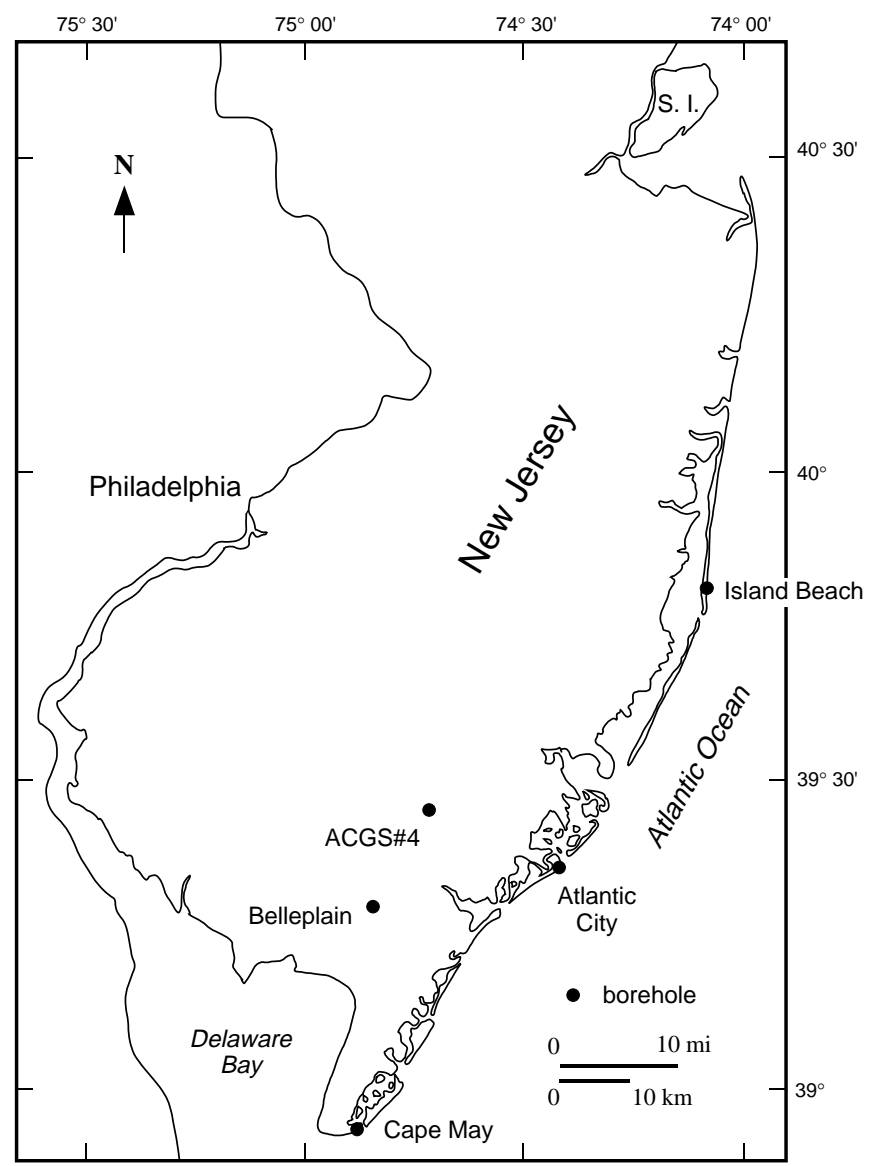

Figure 1. Location of boreholes used in the study. 
Figure 2. Correlation of the Kw0, Kw1a, and Kw $1 \mathrm{~b}$ sequences at ACGS\#4, Atlantic City, and Island Beach boreholes. Also shown are $\mathrm{Sr}$-isotope age estimates (in Ma) and paleoclimatic interpretation. The geologic timescale of Berggren et al. (1995) is used throughout. Depths in feet below land surface.

\section{Atlantic City $\quad$ ACGS\#4 Island Beach}

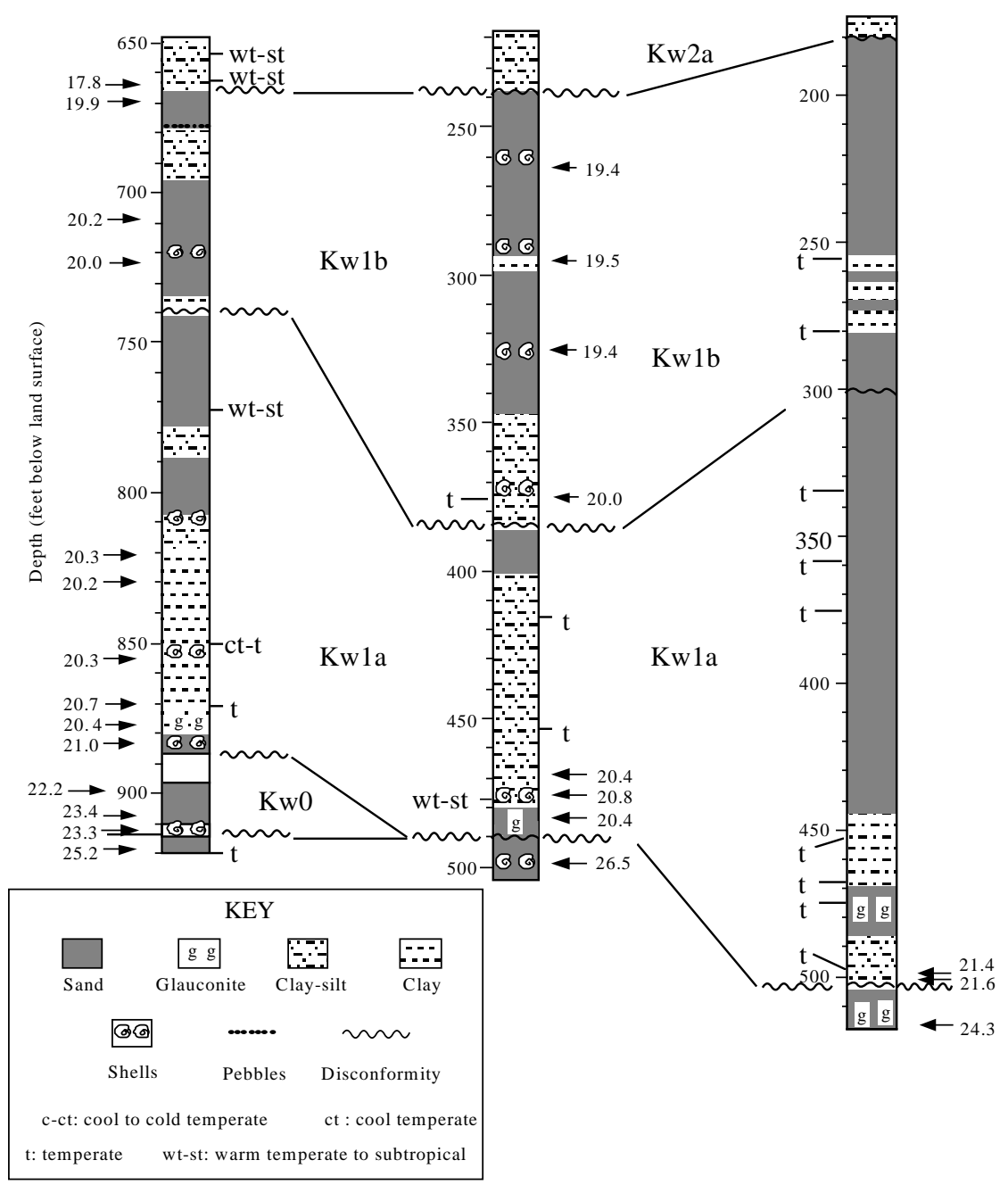

cool to cold temperate. In addition, Table 1 lists genera indicative of swamp environments and exotic genera including plants that are extinct or no longer grow in the region.

Picea, Tsuga, and, to a lesser extent, Alnus and Abies, are indicative of cool to cold temperate climates. Alnus and Picea have been documented as indicative of cool climates (Wolfe, 1978). A change to a Picea-dominated forest from a broadleaf deciduous forest is primarily controlled by summer temperatures, as expressed by the $21^{\circ}$ July isotherm (Wolfe, 1971). In North America, Picea is not native to areas of high summer heat (Wolfe, 1971). Tsuga typically prefers cool microhabitats found in gullies and higher altitudes. Other methods for paleoclimatic interpretation include the use of the Pinus/ Picea ratio, with low ratios interpreted as intervals of climatic cooling (Goldstein, 1974), and the ratio of temperate-warm temperate taxa (Carya, Quercus, Luiquidambar, Nyssa, and Ilex) to subtropicaltropical taxa (Momipites, Cyrilla, Sapotaceae, and Alangium), with high ratios interpreted as cool intervals (Groot, 1992).

\section{RESULTS: POLLEN ASSEMBLAGES AND PALEOCLIMATES}

We did not sample the lowermost Miocene Kw0 sequence for our initial pollen studies because of its limited stratigraphic extent and because the coarse sediments in the sequence are not favorable for pollen preservation. The overlying Kw1 and Kw1b are the most widely represented Miocene sequences in both the subsurface and outcrop (Sugarman et al., 1993). Overall, pollen preserved in the Kw1a (20.1-21.1 Ma; see Miller et al., Chapter 14, this volume, for discussion of chronology) and Kw1b (19.5-20.1 Ma) sequences at the Island Beach, Atlantic City, and the ACGS\#4 boreholes is dominated by temperate to warm temperate forest vegetation (Fig. 2). Quercus-Carya-Pinus is typically the dominant assemblage. Other common to occasional genera include Tsuga, Betula, Carya, Ilex, Podocarpus, and Engelhardia. At the ACGS\#4 borehole, a FagusQuercus assemblage, with lesser amounts of Carya, Pinus, and $\mathrm{Ul}$ mus was reported as the dominant assemblage in the Kw $1 \mathrm{a}$ and $\mathrm{Kw} 1 \mathrm{~b}$ sequences (Owens et al., 1988). At Island Beach, relatively small amounts of Pinus were observed (T. Ager, pers. comm., 1994).

Although the majority of samples contained warm temperate to temperate pollen assemblages, some indications of cooler paleoclimates were found at the base of the Kwla sequence at Island Beach (498 and $475 \mathrm{ft} ; 151.8$ and $144.8 \mathrm{~m}$ ) and near the base of Kw1a at Atlantic City $(850 \mathrm{ft} ; 259.1 \mathrm{~m})$. A well-preserved sample from $850 \mathrm{ft}$ $(259.1 \mathrm{~m})$ at Atlantic City (Sr-isotope age estimate of 20.3 Ma) contained abundant Quercus, common Ilex, Populus, and Tsuga, and occasional Picea, Carya, Nyssa, Engelhardia, Tilia, Alnus, Castanea, Pterocarya, and Betula (Table 2). The mixture of spruce, hemlock, 


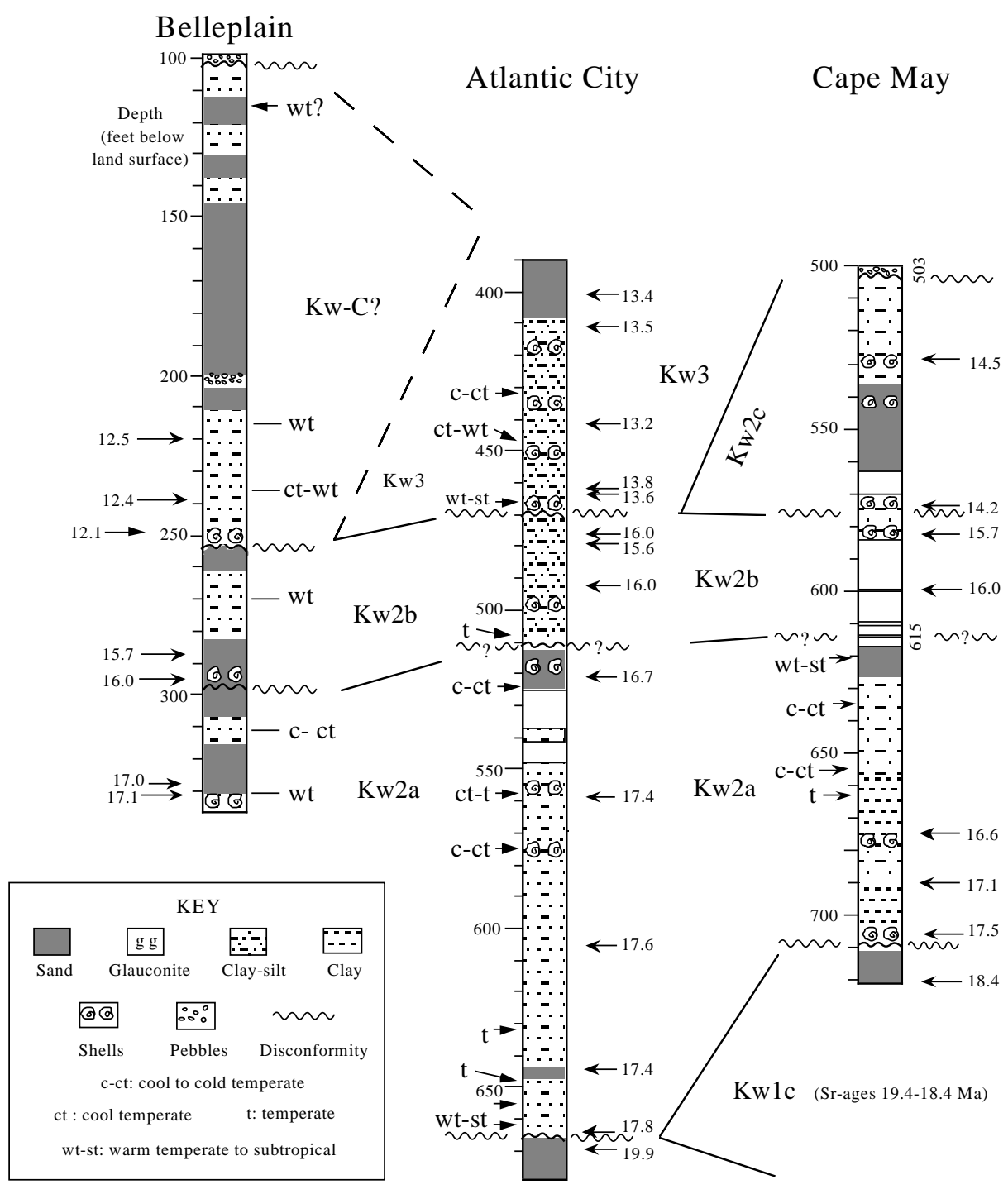

Figure 3. Correlation of the Kw2a, Kw2b, $\mathrm{Kw} 2 \mathrm{c}$, and Kw3 sequences from the Belleplain, Atlantic City, and Cape May boreholes. Also shown are $\mathrm{Sr}$-isotope age estimates (in $\mathrm{Ma}$ ) and paleoclimatic interpretation. The geologic time scale of Berggren et al. (1995) is used throughout. Depths in feet below land surface. alder, and birch indicates a cool temperate climate with evidence of boreal forest assemblages near the source area. Groot (1992) also reports a minor cool interval in the lower Miocene near the base of the Calvert Formation. At Island Beach, samples from the base of the Kwla sequence contained a higher diversity and greater abundance of conifer pollen (e.g., Pinaceae and Taxodiacea), along with Picea and Alnus, suggesting possible cooler (temperate instead of warm temperate) climatic conditions.

No pollen was examined from the Kw1c sequence, which was only recovered at Cape May.

The Kw2a sequence (16.5-17.8 Ma) records a distinct regional climatic cooling. At Atlantic City, palynological results indicate that the transgressive deposits at the base of the Kw2a sequence at $662 \mathrm{ft}$ and $656 \mathrm{ft}$ (201.8 and $199.9 \mathrm{~m}$ ) record warm to subtropical paleoclimates. Quercus and Carya are the dominant taxa, with lesser Engelhardia. A cooling from warm temperate to temperate paleoclimates is recorded slightly higher in the sequence (649 and $632 \mathrm{ft} ; 197.8$ and $192.6 \mathrm{~m})$. The dominant taxa are similar to those from $662 \mathrm{ft}(201.8$ $\mathrm{m})$ and $656 \mathrm{ft}(199.9 \mathrm{~m})$, with the addition of Pinus at $649 \mathrm{ft}(197.8$ $\mathrm{m})$. A major transition to cooler climates is observed in the regressive sediments from the upper part of the Kw2a sequence (Fig. 3). In this interval, the dominant assemblage changes from Quercus and Carya to Quercus, Picea, and Carya, a cool to cold temperate assemblage. In addition, Tsuga and Alnus, also indicative of cool climates, are present in trace amounts. The assemblage from $525 \mathrm{ft}(160 \mathrm{~m})$ also includes small amounts of Pinus, Betula, Fagus, and Tilia. Overall, the Kw2a sequence from Atlantic City can be characterized as an upward cooling sequence (Fig. 3).

Pollen data from the upper part of the Kw2a sequence at Belleplain $(330 \mathrm{ft}$ and $311 \mathrm{ft} ; 110.6$ and $94.8 \mathrm{~m}$; Sr age estimate of 17.0 $\mathrm{Ma})$ also indicate a cooling. The sample at $311 \mathrm{ft}(94.8 \mathrm{~m})$ contains Pinus and Picea, in addition to the exotics Clethra, Podocarpus, Cyrilla, Engelhardia/Momipites, Symplocus, and Gordonia. This sample contains both warm temperate to subtropical trees and exotics, and warm to cool temperate trees with spruce (L. Sirkin, pers. comm., 1991). The sample from $330 \mathrm{ft}(110.6 \mathrm{~m})$ contains a less diverse assemblage dominated by Quercus, Carya, and Pinus, with lesser Engelhardia and Planera. This limited assemblage is typical of warm temperate to temperate paleoclimates.

The Kw2a sequence at Cape May is consistent with an upsection cooling. A sample at $663 \mathrm{ft}(202.1 \mathrm{~m})$ contains a poor pollen assemblage that nonetheless indicates a probable temperate paleoclimate. Above this, a Quercus, Picea, and Carya-dominated assemblage at 653 and $637 \mathrm{ft}(199.0$ and $194.2 \mathrm{~m})$ indicates cool to cold temperate environments (Table 3). The assemblage at $653 \mathrm{ft}(199.0 \mathrm{~m})$ also contains sparse Alnus and Tsuga, whereas at $637 \mathrm{ft}$, Betula, Fagus, Pterocarya, and Acer are sparsely present. The overlying sample $(620.6 \mathrm{ft}[189.2 \mathrm{~m}])$ had poor recovery of pollen, although it probably indicates a temperate environment.

Limited palynological data from the Kw2b sequence (15.6-16.1 $\mathrm{Ma})$ at Atlantic City (509 ft [155.1 m]) and Belleplain (270 ft [82.3 $\mathrm{m}]$ ) are dominated by temperate (and to a lesser extent, cool temper- 
Table 1. Climatic and paleoenvironmental indicator genera.

\begin{tabular}{|c|c|c|c|c|}
\hline $\begin{array}{l}\text { Warm temperate to } \\
\text { subtropical genera }\end{array}$ & $\begin{array}{c}\text { Temperate } \\
\text { genera }\end{array}$ & $\begin{array}{l}\text { Cool to cold } \\
\text { temperate genera }\end{array}$ & $\begin{array}{c}\text { Swamp-associated } \\
\text { genera }\end{array}$ & Exotic genera \\
\hline $\begin{array}{l}\text { Engelhardia } \\
\text { Alangium } \\
\text { Manilkara } \\
\text { Cyrilla } \\
\text { Planera } \\
\text { Gordonia } \\
\text { Symplocos } \\
\text { Podocarpus } \\
\text { Taxodium } \\
\text { Glyptostrobus } \\
\text { Jussiaea } \\
\text { Cyathea } \\
\text { Nyssa } \\
\text { Magnolia }\end{array}$ & $\begin{array}{l}\text { Carya } \\
\text { Quercus } \\
\text { Luiquidamber } \\
\text { Nyssa } \\
\text { Ilex } \\
\text { Fagus } \\
\text { Tilia } \\
\text { Castanea } \\
\text { Ulmus } \\
\text { Pterocarya }\end{array}$ & $\begin{array}{l}\text { Picea } \\
\text { Abies } \\
\text { Alnus } \\
\text { Tsuga }\end{array}$ & $\begin{array}{l}\text { Engelhardia } \\
\text { Alnus } \\
\text { Ilex } \\
\text { Liquidamber } \\
\text { Nyssa } \\
\text { Planera } \\
\text { Symplocos } \\
\text { Taxodium } \\
\text { Glyptostrobus } \\
\text { Cyrilla }\end{array}$ & $\begin{array}{l}\text { Glyptostrobus } \\
\text { Engelhardia } \\
\text { Pterocarya } \\
\text { Alangium } \\
\text { Symplocos } \\
\text { Podocarpus }\end{array}$ \\
\hline
\end{tabular}

ate) assemblages. The Kw2b sequence is thin, has poor recovery at Cape May, and is sandy, limiting further palynological interpretation.

No pollen was examined from the $\mathrm{Kw} 2 \mathrm{c}$ sequence, which was only recovered at Cape May.

Incomplete data in the Kw3 sequence limits resolution, although there is an indication of an upsection cooling at Atlantic City. The base of the Kw3 at Atlantic City (463 ft [141.1 m]) contains a dominant Quercus, Fagus, Ulmus assemblage, along with minor percentages of taxa indicative of warm to subtropical paleoenvironments (Table 2). Sixteen feet $(\sim 5 \mathrm{~m})$ higher in the borehole at $447 \mathrm{ft}$ (136.2 m), common Picea, Alnus, with occasional Tsuga and Abies, characteristic of cool temperate conditions, signal a major change in pollen assemblages. At $432 \mathrm{ft}(131.7 \mathrm{~m})$, the assemblage is dominated by Quercus, Picea, and Tsuga, interpreted to indicate a cool to cold temperate paleoclimate. Thus, the Kw3 sequence at the Atlantic City borehole also appears to cool upward into the regressive section of the sequence, similar to the Kw2a sequence. At the base of the $\mathrm{Kw}-\mathrm{C}$ sequence at the Belleplain State Forest borehole, a mixture of cool and warm temperate pollen assemblages are present at $236 \mathrm{ft}$ (71.9 m). The sample contains a Quercus, Carya, and Pinus-dominated suite, along with abundant Picea and rare exotics indicative of warm temperate to subtropical conditions including Podocarpus, Planera, Engelhardia/Momipites, Cyrilla, and Symplocus. Additional samples from the Kw3 sequence at Belleplain at $216 \mathrm{ft}$ and $115 \mathrm{ft}$ (65.8 and $35.1 \mathrm{~m}$ ) contained a poorly preserved warm temperate assemblage. Overall, the $\mathrm{Kw}-\mathrm{C}$ sequence at Belleplain has some cool climatic indicators at its base, with the limited data indicating a possible warming trend upward. Further study of this section at Belleplain is required.

\section{DISCUSSIONS AND CONCLUSIONS}

Overall, the pollen assemblages from the Kw1 sequence (19.5$21.1 \mathrm{Ma}$ ) represent temperate to warm temperate predominantly broadleaf, deciduous forest vegetation. The dominance of Quercus, Carya, and Pinus pollen, along with the minor presence of taxa that grow in subtropical to tropical regions, indicate a warm temperate climate prevailed during the early Miocene. Some minor cooling events may have marked this period of relative climatic stability. For example, the pollen sample from the Atlantic City borehole at $850 \mathrm{ft}(259.1$ m) contained a cooler assemblage, including Picea, Tsuga, and Alnus, indicating a cooler climatic interval at $20.3 \mathrm{Ma}$.

The long hiatus (19.5-17.8 Ma) between the Kw1 and Kw2 sequences at most boreholes precludes any possible palynologic analysis and paleoclimatic interpretations for this early Miocene interval, although future studies of the Kw1c (18.4-19.4 Ma) may shed some light on paleoclimate at this time.

A change in palynologic assemblages occurred at $\sim 17.6 \mathrm{Ma}$ (within the Kw2 sequence), recording a major climatic transition in the late early Miocene. Picea becomes common, whereas taxa indicative of warm temperate to subtropical conditions become rare at both Atlantic and Cape May (Fig. 3; Table 2). This major cooling is several million years older than the major middle Miocene cooling and ice growth event recorded in the marine realm (Miller et al., 1991; Flower and Kennett, 1994), although it may correlate with cooling associated with the Milb $\delta^{18} \mathrm{O}$ maxima (Fig. 4).

Our preliminary sequence stratigraphic interpretations of pollen and terrestrial climate changes are inconclusive. Groot (1992) suggested that the cooler taxa preserved in coastal plain deposits may not be controlled by regional or global climate, but by relative sea level. For example, during transgressions (i.e., in the basal portions of sequences) and times of higher sea level, pollen may be derived directly from regions of higher elevation than the coastal plain, such as the Piedmont or Appalachians, allowing higher percentages of cooler taxa to be preserved. This study does not confirm this hypothesis as the warmer assemblages have been found at the base, or transgressive portion of the Kirkwood 2a sequence, whereas the cooler assemblages occur in the regressive, or shallower water facies.

\section{REFERENCES}

Berggren, W.A., Kent, D.V., Swisher, C.C., III, and Aubry, M.-P., 1995. A revised Cenozoic geochronology and chronostratigraphy. In Berggren, W.A., Kent, D.V., Aubry, M.-P., and Hardenbol, J. (Eds.), Geochronology, Time Scales and Global Stratigraphic Correlation. Spec. Publ.Soc. Econ. Paleontol. Mineral., 54:129-212.

Flower, B.P., and Kennett, J.P., 1994. The middle Miocene climatic transition: East Antartic ice sheet development, deep ocean circulation and global carbon cycling. Palaeogeogr., Palaeoclimatol., Palaeoecol., 108:537-555.

Goldstein, F.R., 1974. Paleoenvironmental analysis of the Kirkwood Formation [Ph.D. dissert.]. Rutgers Univ., New Brunswick, NJ.

Groot, J.J., 1992. Plant microfossils of the Calvert Formation of Delaware. Delaware Geol. Surv. Rept. Investigations, 50.

Miller, K.G., et al., 1994. Proc. ODP, Init. Repts., 150X: College Station, TX (Ocean Drilling Program).

Miller, K.G., et al., 1996a. Proc. ODP, Init. Repts., 150X (Suppl.): College Station, TX (Ocean Drilling Program).

Miller, K.G., Mountain, G.S., Blum, P., Gartner, S., Alm Per G., Aubry, M.-P., Burckle, L.H., Guerin, G., Katz, M.E., Christensen, B.A., Compton, J., Damuth, J.E., Deconinck, J.F.,de Verteuil, L., Fulthorpe, C.S., Hesselbo, S.P., Hoppie, B.W., Kotake, N., Lorenzo, J.M., McCracken, S., McHugh, C.M., Quayle, W.C., Saito, Y., Snyder, S.W., ten Kate, W.G., Urbat, M., Van Fossen, M.C., Vecsei, A., Sugarman, P.J., Mullikin, L., Pekar, S., Browning, J.V., Liu, C., Feigenson, M.D., Goss, M., Gwynn, D., Queen, D.G., Powars, D.S., Heibel, T.D., Bukry, D., 1996b. Drilling and dating New Jersey Oligocene-Miocene sequences: ice volume, global sea level, and Exxon records, Science, 271:1092-1095.

Miller, K.G., Wright, J.D., and Fairbanks, R.G., 1991. Unlocking the Ice House: Oligocene-Miocene oxygen isotopes, eustasy, and margin erosion. J. Geophys. Res., 96:6829-6848.

Owens, J.P., Bybell, L.M., Paulachok, G., Ager, T.A., Gonzalez, V.M., and Sugarman, P.J., 1988. Stratigraphy of the Tertiary sediments in a 945foot-deep core hole near Mays Landing in the southeastern New Jersey Coastal Plain. Geol. Surv. Prof. Pap. U.S., 1484. 
Owens, J.P., Sugarman, P.J., Sohl, N.F., and Orndorff, R.C., 1995a. Geologic map of New Jersey: Southern Sheet. Open-File Rep.-U.S. Geol. Surv., 95-254.

Owens, J.P., Sugarman, P.J., Sohl, N.F., Parker, R., Houghton, H.H., Volkert, R.V., Drake, A.A., and Orndorff, R.C., 1995b. Geologic map of New Jersey: Central Sheet. Open-File Rep.-U.S. Geol. Surv., 95-253.

Savin, S.M., Abel, L., Barrera, E., Hodell, D.A., Keller, G., Kennett, J.P., Killingley, J., Murphy, M., and Vincent, E., 1985. The evolution of Miocene surface and near-surface marine temperatures: oxygen isotopic evidence. In Kennett, J.P. (Ed.), The Miocene Ocean: Paleoceanography and Biogeography. Mem.-Geol. Soc. Am., 163,49-82.
Sugarman, P.J., Miller, K.G., Owens, J.P., and Feigenson, M.D., 1993. Strontium-isotope and sequence stratigraphy of the Miocene Kirkwood Formation, southern New Jersey. Geol. Soc. Am. Bull., 105:423-436.

Wolfe, J.A., 1971. Tertiary climatic fluctuations and methods of analysis of Tertiary floras. Palaeogeogr., Palaeoclimatol., Palaeoecol., 9:27-57. , 1978. A paleobotanical interpretation of Tertiary climates in the Northern Hemisphere. Am. J. Sci., 66:694-703.

Date of initial receipt: 17 April 1996

Date of acceptance: 14 August 1996

Ms 150XSR-311 
Table 2. Pollen assemblages and paleoclimates of the Atlantic City borehole.

\begin{tabular}{|c|c|c|c|c|c|c|c|c|c|c|c|c|c|c|c|}
\hline Paleoclimate: & Temperate & Temperate & Temperate & $\begin{array}{l}\text { Warm to } \\
\text { subtropical }\end{array}$ & $\begin{array}{c}\text { Warm to } \\
\text { subtropical }\end{array}$ & $\begin{array}{c}\text { Warm to } \\
\text { subtropical }\end{array}$ & Temperate & Temperate & $\begin{array}{c}\text { Cool to } \\
\text { temperate }\end{array}$ & $\begin{array}{l}\text { Cool to cold } \\
\text { temperate }\end{array}$ & $\begin{array}{l}\text { Cool to cold } \\
\text { temperate }\end{array}$ & Temperate & $\begin{array}{c}\text { Warm to } \\
\text { subtropical }\end{array}$ & $\begin{array}{l}\text { Cool to } \\
\text { warm } \\
\text { temperate }\end{array}$ & $\begin{array}{l}\text { Cool to cold } \\
\text { temperature }\end{array}$ \\
\hline Dominants: & Pine-Hickory & Pine-Oak & $\begin{array}{l}\text { Oak-Hickory- } \\
\text { Hemlock }\end{array}$ & Oak-Pine & Hickory & Oak-Hickory & $\begin{array}{l}\text { Oak-Hickory- } \\
\text { Pine }\end{array}$ & Oak-Hickory & $\begin{array}{l}\text { Oak-Spruce- } \\
\text { Hickory }\end{array}$ & $\begin{array}{l}\text { Oak-Spruce- } \\
\text { Hickory }\end{array}$ & $\begin{array}{l}\text { Oak-Spruce- } \\
\text { Hickory }\end{array}$ & Oak-Hickory & $\begin{array}{l}\text { Oak-Beech- } \\
\text { Elm }\end{array}$ & $\begin{array}{l}\text { Oak-Spruce- } \\
\text { Pine }\end{array}$ & $\begin{array}{l}\text { Oak-Spruce- } \\
\text { Hemlock }\end{array}$ \\
\hline Sample depth (ft): & 932.2 & 870 & 850 & 773 & 662 & 656 & 649 & 632 & 575 & 554 & 525 & 509 & 467.2 & 447 & 431.7 \\
\hline Palynological recovery: & Very poor & Fair & Excellent & Poor & Poor & Fair & Poor & Fair & Good & Excellent & Good & Good & Excellent & Excellent & Excellent \\
\hline Kw sequence: & - & $1 \mathrm{a}$ & $1 \mathrm{a}$ & 1a & $2 \mathrm{a}$ & $2 \mathrm{a}$ & $2 \mathrm{a}$ & $2 \mathrm{a}$ & $2 \mathrm{a}$ & $2 \mathrm{a}$ & $2 \mathrm{a}$ & $2 \mathrm{~b}$ & 3 & 3 & 3 \\
\hline \multicolumn{16}{|l|}{ Cool/cold genera } \\
\hline Picea & $\mathrm{R}$ & - & $\mathrm{O}$ & $\mathrm{R}$ & - & - & $\mathrm{R}$ & $\mathrm{O}$ & $\mathrm{C}$ & $\mathrm{C}$ & $\mathrm{C}$ & $\mathrm{R}$ & $\mathrm{R}$ & C & C \\
\hline Abies & - & - & - & & - & - & - & - & - & & & $\mathrm{O}$ & $\mathrm{R}$ & $\mathrm{O}$ & $\mathrm{O}$ \\
\hline Tsuga & - & - & $\mathrm{C}$ & $\mathrm{R}$ & - & - & - & - & - & $\mathrm{R}$ & $\mathrm{R}$ & - & $\mathrm{R}$ & $\mathrm{O}$ & $\mathrm{C}$ \\
\hline Alnus & - & - & $\mathrm{O}$ & - & - & - & - & - & $\mathrm{R}$ & $\mathrm{R}$ & - & $\mathrm{O}$ & $\mathrm{R}$ & $\mathrm{C}$ & $\mathrm{O}$ \\
\hline \multicolumn{16}{|l|}{ Temperate genera } \\
\hline Pinus & $\mathrm{C}$ & A & $\dot{0}$ & $\mathrm{O}$ & - & - & $\begin{array}{l}\mathrm{C} \\
\mathrm{R}\end{array}$ & ${ }_{\mathrm{R}}^{\mathrm{O}}$ & $R$ & R & $\mathrm{O}$ & - & $\mathrm{R}$ & ${ }_{\mathrm{P}}^{\mathrm{C}}$ & $\mathrm{C}$ \\
\hline $\begin{array}{l}\text { Betula } \\
\text { Carya }\end{array}$ & $\overline{\mathrm{A}}$ & - & $\mathrm{C}$ & $\bar{R}$ & $\overline{\mathrm{C}}$ & $\overline{\mathrm{O}}$ & $\begin{array}{l}\mathrm{K} \\
\mathrm{A}\end{array}$ & $\mathrm{K}$ & $\begin{array}{l}\mathrm{K} \\
\mathrm{C}\end{array}$ & $\mathrm{C}$ & $\mathrm{C}$ & $\overline{\mathrm{A}}$ & $\begin{array}{l}\mathrm{R} \\
-\end{array}$ & $\mathrm{C}$ & $\overline{\mathrm{C}}$ \\
\hline Quercus & $\mathrm{O}$ & $\mathrm{C}$ & A & $\mathrm{O}$ & - & $\mathrm{C}$ & A & A & A & A & A & A & A & A & A \\
\hline Liquidamber & - & - & - & - & $\mathrm{R}$ & - & - & - & - & $\mathrm{R}$ & - & - & $\mathrm{R}$ & C & C \\
\hline Fagus & - & - & - & $\mathrm{R}$ & - & - & $\mathrm{R}$ & - & $\mathrm{R}$ & $\mathrm{R}$ & $\mathrm{O}$ & $\mathrm{R}$ & $\mathrm{C}$ & $\mathrm{R}$ & $\mathrm{R}$ \\
\hline Tilia & - & $\mathrm{O}$ & $\mathrm{O}$ & - & - & $\mathrm{R}$ & & - & & & $\mathrm{O}$ & $\mathrm{R}$ & & $\mathrm{R}$ & $\mathrm{R}$ \\
\hline Ulmus & - & - & - & - & - & - & $\mathrm{R}$ & - & $\mathrm{R}$ & $\mathrm{R}$ & & $\mathrm{R}$ & $\mathrm{O}$ & $\mathrm{C}$ & $\mathrm{O}$ \\
\hline Pterocarya & - & - & - & - & - & - & - & $\mathrm{R}$ & - & - & $\mathrm{R}$ & $\mathrm{R}$ & & & \\
\hline Ilex & - & - & C & - & - & - & - & - & - & $\mathrm{C}$ & - & - & $\mathrm{R}$ & $\mathrm{R}$ & \\
\hline Castanea & - & - & $\mathrm{O}$ & - & - & - & $\mathrm{R}$ & - & - & - & - & $\mathrm{R}$ & - & - & - \\
\hline Juglans & - & - & $\mathrm{R}$ & - & - & - & - & - & - & - & $\mathrm{R}$ & - & - & - & $\mathrm{O}$ \\
\hline Acer & - & - & - & - & - & - & - & - & - & - & $\mathrm{R}$ & - & $\mathrm{R}$ & $\mathrm{R}$ & $\mathrm{R}$ \\
\hline \multicolumn{16}{|c|}{ Warm temperate to subtropical genera } \\
\hline Engelhardia & $\mathrm{R}$ & - & $\mathrm{O}$ & - & - & $\mathrm{O}$ & - & - & - & - & $\mathrm{R}$ & $\mathrm{C}$ & $\mathrm{R}$ & $\mathrm{R}$ & - \\
\hline Alangium & - & - & - & - & - & - & - & - & - & - & - & - & - & - & - \\
\hline Manilkara & - & - & - & - & - & - & - & - & - & - & - & - & $\mathrm{R}$ & - & - \\
\hline Cyrilla & - & - & - & $\mathrm{R}$ & - & - & - & - & - & - & - & - & $\mathrm{R}$ & - & - \\
\hline Planera & - & - & - & - & - & - & - & - & - & - & - & - & $\mathrm{R}$ & - & - \\
\hline Gordonia & - & - & $\mathrm{R}$ & - & - & $\mathrm{O}$ & $\mathrm{R}$ & - & - & - & - & -- & - & - & - \\
\hline Symplocos & - & - & - & - & - & - & 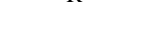 & - & - & - & - & - & $\mathrm{R}$ & $\mathrm{R}$ & - \\
\hline Podocarpus & $\mathrm{O}$ & $\mathrm{R}$ & $\mathrm{R}$ & - & - & - & - & - & - & - & $\mathrm{R}$ & $\mathrm{R}$ & $\mathrm{R}$ & - & - \\
\hline Taxodium & - & $\mathrm{R}$ & - & - & $\mathrm{R}$ & - & - & - & - & - & - & - & $\mathrm{O}$ & - & - \\
\hline Glyptostrobus & - & - & - & - & - & - & - & - & - & - & - & - & - & - & - \\
\hline Jussiaea & - & - & - & $\mathrm{R}$ & - & $\overline{\mathrm{D}}$ & - & - & - & - & - & - & - & - & - \\
\hline Cyathea & - & - & - & - & - & $\mathrm{R}$ & - & - & - & - & - & $\mathrm{R}$ & - & - & - \\
\hline Nyssa & - & - & $\mathrm{R}$ & - & - & $\mathrm{R}$ & - & - & - & - & $\mathrm{R}$ & - & - & $\mathrm{R}$ & \\
\hline Cycadaceae & - & - & - & - & - & - & - & - & - & - & - & - & - & - & $\mathrm{R}$ \\
\hline Ostrya & - & - & $\mathrm{R}$ & $\mathrm{R}$ & $\mathrm{R}$ & - & - & - & - & - & - & - & - & - & $\mathrm{R}$ \\
\hline Magnolia & - & - & $\mathrm{R}$ & - & - & - & - & - & - & - & - & - & - & - & - \\
\hline
\end{tabular}

Notes: - = none present. $\mathrm{R}=$ rare; less than $1 \% . \mathrm{O}=$ occasional; $1 \%-5 \% . \mathrm{C}=$ common; $6 \%-10 \% . \mathrm{A}=$ abundant; greater than $10 \% .200$ grains were counted per sample. 
Table 3. Pollen assemblages and paleoclimates of the Cape May borehole.

\begin{tabular}{|c|c|c|c|c|c|}
\hline Paleoclimate: & $?$ & Temperate & Cool to cold temperate & Cool to cold temperate & Warm to subtropical \\
\hline Dominants: & & & Spruce-Pine-Oak & Spruce-Pine-Oak & \\
\hline Sample depth $(\mathrm{ft})$ : & $673-673.8$ & 663.2 & 651.4 & $636.6-636.8$ & $620.4-620.6$ \\
\hline Palynological recovery: & Very Poor & Poor & Good & Good & Poor \\
\hline Kw sequence: & $2 \mathrm{a}$ & $2 \mathrm{a}$ & $2 \mathrm{a}$ & $2 \mathrm{a}$ & $2 \mathrm{a}$ \\
\hline Sr-isotopic age (Ma): & 16.9 & - & 16.8 & 16.6 & 16.5 \\
\hline \multicolumn{6}{|l|}{$\mathrm{Cool} /$ Cold genera } \\
\hline Picea & $\mathrm{x}$ & $\mathrm{X}$ & $\mathrm{C}$ & A & - \\
\hline Abies & - & $\mathrm{X}$ & - & - & - \\
\hline Tsuga & - & - & $\mathrm{O}$ & $\mathrm{R}$ & $\mathrm{O}$ \\
\hline Alnus & - & - & $\mathrm{O}$ & - & - \\
\hline \multicolumn{6}{|l|}{ Temperate genera } \\
\hline Pinus & - & $\mathrm{X}$ & A & C & ${ }_{\mathrm{P}}^{\mathrm{O}}$ \\
\hline $\begin{array}{l}\text { Betula } \\
\text { Carya }\end{array}$ & $\overline{\mathrm{X}}$ & - & $\overline{\mathrm{C}}$ & $\stackrel{\mathrm{O}}{\mathrm{C}}$ & $\begin{array}{l}\mathrm{R} \\
\mathrm{O}\end{array}$ \\
\hline Quercus & - & - & A & $\mathrm{C}$ & $\mathrm{R}$ \\
\hline Liquidamber & - & - & - & - & $\mathrm{R}$ \\
\hline Fagus & - & $\mathrm{X}$ & - & $\mathrm{O}$ & - \\
\hline Tilia & - & - & - & - & - \\
\hline Ulmus & - & - & - & - & - \\
\hline Pterocarya & - & - & - & $\mathrm{O}$ & - \\
\hline Ilex & - & - & - & - & - \\
\hline Castanea & - & - & - & - & - \\
\hline Juglans & - & $\mathrm{X}$ & - & - & - \\
\hline Acer & - & - & - & $\mathrm{O}$ & $\mathrm{R}$ \\
\hline \multicolumn{6}{|c|}{ Warm temperate to subtropical genera } \\
\hline Engelhardia & - & - & - & - & - \\
\hline Alangium & - & - & - & - & - \\
\hline Manilkara & - & - & - & - & - \\
\hline Cyrilla & - & & - & - & $\mathrm{R}$ \\
\hline Planera & - & - & - & - & - \\
\hline Gordonia & - & - & - & - & - \\
\hline Symplocos & - & - & - & - & - \\
\hline Podocarpus & - & - & - & - & - \\
\hline Taxodium & - & - & - & - & $\mathrm{R}$ \\
\hline Glyptostrobus & - & - & - & - & - \\
\hline Jussiaea & - & - & - & - & - \\
\hline Cyathea & - & - & - & - & $\mathrm{R}$ \\
\hline Nyssa & - & - & - & - & - \\
\hline Cycadaceae & - & - & - & - & - \\
\hline Ostrya & - & - & - & - & - \\
\hline Magnolia & - & - & - & - & - \\
\hline
\end{tabular}

Notes: - = none present. $\mathrm{X}=$ present; used in samples with poor to very poor palynological recovery. $\mathrm{C}=$ common; $6-10 \% . \mathrm{A}=\mathrm{abundant} ;$ greater than $10 \% . \mathrm{O}=$ occasional; $1 \%-5 \%$. $\mathrm{R}=$ rare; less than $1 \% .200$ grains were counted per sample.

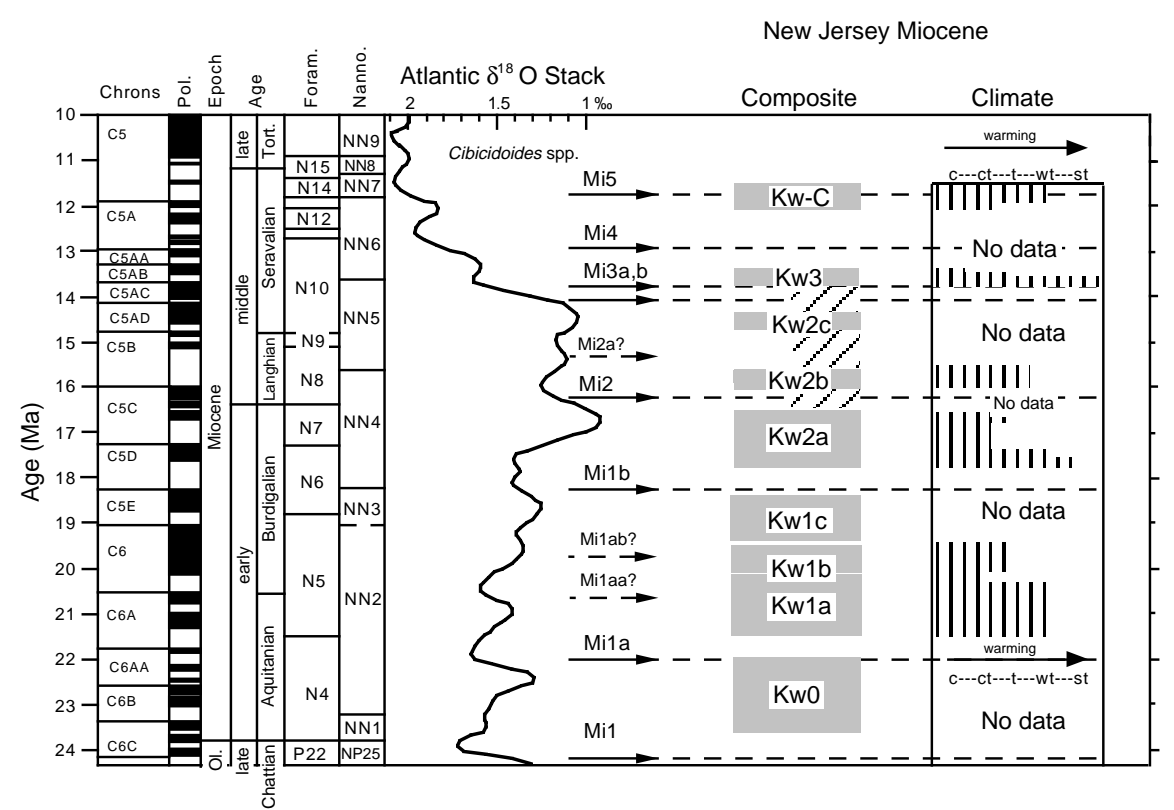

Figure 4. Comparison of the stacked Atlantic $\delta^{18} \mathrm{O}$ record with the composite record of deposition at the three Leg $150 \mathrm{X}$ boreholes, and the generalized paleoclimatic records developed from pollen data. Pol. = polarity; Foram. $=$ foraminiferal zonation; Nanno. $=$ nannofossil zonation. Other abbreviations as in Figures 2 and 3 . 

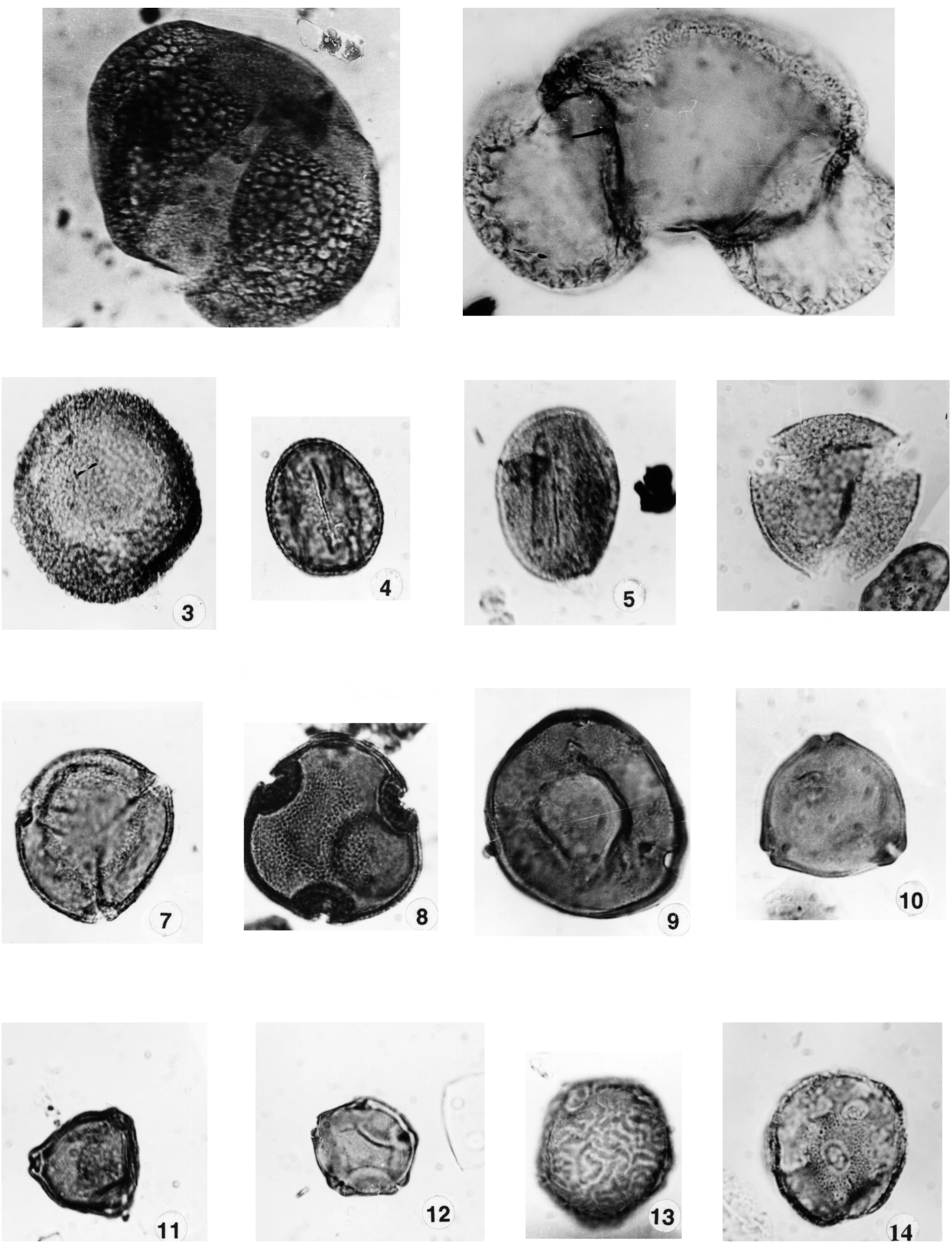

Plate 1. Common lower to middle Miocene pollen taxa, Leg 150X, Atlantic City (AC) and Cape May (CM) boreholes. 1. Picea (spruce), Sample CM 150X, 636.6-636.8 ft, maximum diameter $140.4 \mu \mathrm{m}$. 2. Pinus (pine), AC 150X, 431.7-432 ft, maximum diameter $71 \mu \mathrm{m}$. 3. Tsuga (hemlock), CM 150X, 636.6-636.8 $\mathrm{ft}$, maximum diameter $91 \mu \mathrm{m}$. 4. Quercus type 1, AC 150X, 467.2-467.4 ft, maximum diameter $29 \mu \mathrm{m}$. 5. Quercus type 2, AC 150X, $467.2-467.4 \mathrm{ft}$, maximum diameter $35 \mu \mathrm{m}$. 6. Acer (maple), AC 150X 467.2-467.4 ft, maximum diameter $34 \mu \mathrm{m}$. 7. Fagus (beech), AC 150X, $431.7-432 \mathrm{ft}$, maximum diameter $35 \mu \mathrm{m}$. 8. Tilia (linden), CM 150X, $651.4 \mathrm{ft}$, maximum diameter $37 \mu \mathrm{m}$. 9. Carya (hickory), CM 150X, $651.4 \mathrm{ft}$, maximum diameter $43 \mu \mathrm{m}$. 10. Betula (birch), CM 150X, 636.6-636.8 ft, maximum diameter $31 \mu \mathrm{m}$. 11. Betula (birch), CM 150X, 651.4 ft, maximum diameter $22 \mu \mathrm{m}$. 12. Alnus (alder) AC 150X, 431.7-432 ft, maximum diameter $23 \mu \mathrm{m}$. 13. Ulmus (elm), AC 150X, 431.7-432 ft, maximum diameter $29 \mu \mathrm{m}$. 14. Liquidamber (sweet gum) AC 150X 431.7-432 ft, maximum diameter $31 \mu \mathrm{m}$. 

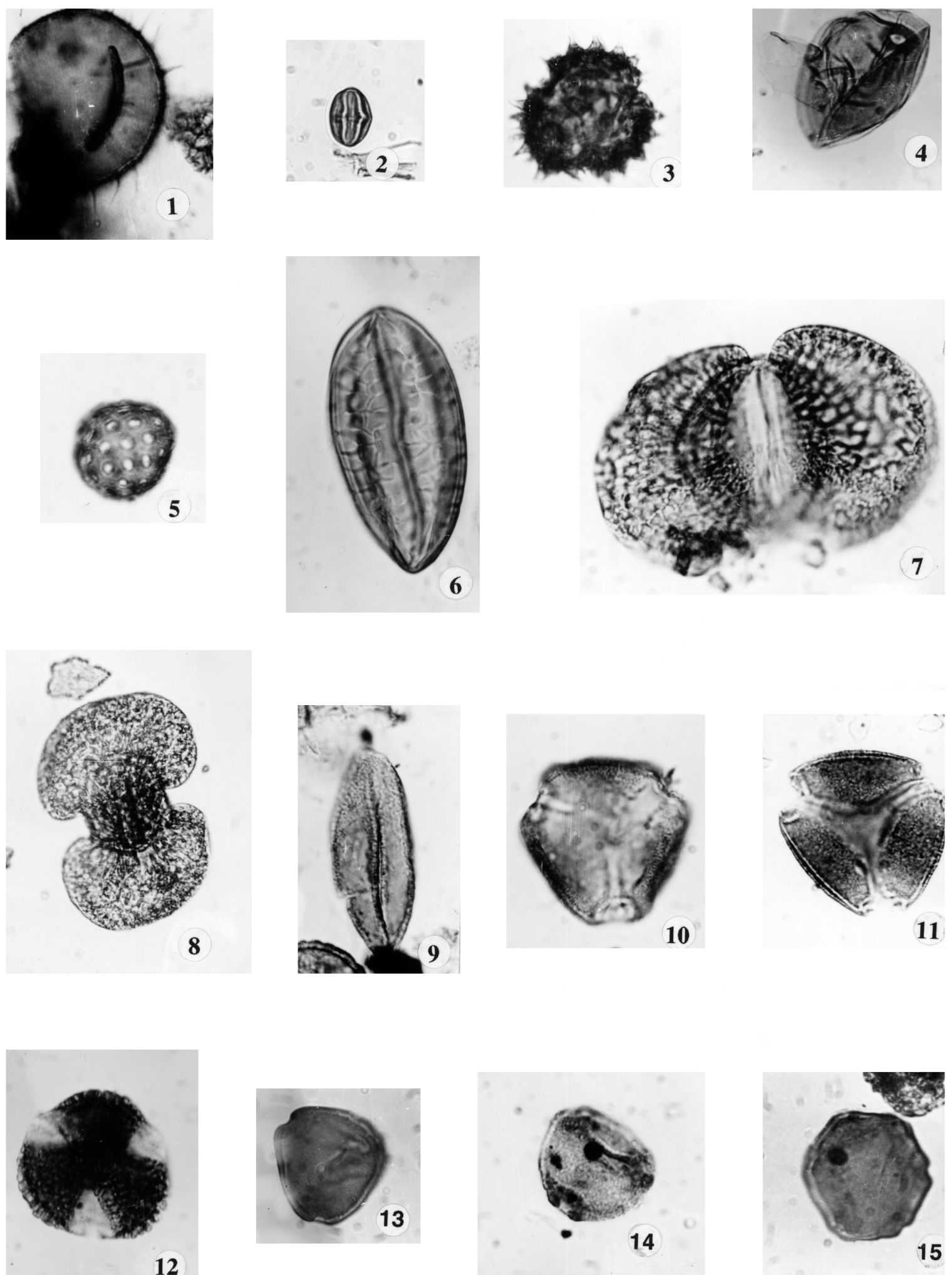

Plate 2. Rare and exotic lower to middle Miocene pollen taxa, Leg 150X, Atlantic City (AC) and Cape May (CM) boreholes. 1. Nymphea (water lily), AC 150X, 467.2-467.4 ft, maximum diameter $38 \mu \mathrm{m}$. 2. Castanea (chestnut), AC 150X, 467.2-467.4 ft, maximum diameter $12 \mu \mathrm{m}$. 3. Compositae-Tubuliflorae, AC 150X, 431.7-432 ft, maximum diameter $28 \mu \mathrm{m}$. 4. Gramineae (grass) AC 150X, 467.2-467.4 ft, maximum diameter $34 \mu \mathrm{m}$. 5. Chenopodium (goosefoot), AC 150X, 431.7-432 ft, maximum diameter $21 \mu \mathrm{m}$. 6. Ephedra, CM 150X, $651.4 \mathrm{ft}$, maximum diameter $53 \mu \mathrm{m}$. 7. Podocarpus type 1, AC 150X, 447-448 ft, maximum diameter $107 \mu \mathrm{m}$. 8. Podocarpus type 2, AC 150X, 447-448 ft, maximum diameter $70 \mu \mathrm{m}$. 9. Magnolia, AC 150X, 431.7-432ft, maximum diameter 42 $\mu \mathrm{m}$. 10. Nyssa type 1 (gum), AC 150X 447-448 ft, maximum diameter $34 \mu \mathrm{m}$. 11. Nyssa type 2 (gum), AC 150X, 431.7-432 ft, maximum diameter $34 \mu \mathrm{m} .12$. Gordonia, AC 150X, 467.2-467.4 ft, maximum diameter $30 \mu \mathrm{m}$. 13. Engelhardia, AC 150X, 467.2-467.4 ft, maximum diameter $24 \mu \mathrm{m}$. 14. Symplocos, AC 150X, 467.2-467.4 ft, maximum diameter $23 \mu \mathrm{m}$. 15. Pterocarya, CM 150X, 636.6-636.8 ft, maximum diameter $26 \mu \mathrm{m}$. 